This article was published in Pneuma 35/3 (2011). Below is the manuscript form of the final, peerreviewed accepted version. For the typeset published version, see http://booksandjournals.brillonline.com/content/journals/10.1163/15700747-12341348.

Author's present contact information:

Dr. Jörg Haustein, SOAS University of London

joerg.haustein@soas.ac.uk

\title{
Historical Epistemology and Pentecostal Origins: History and Historiography in Ethiopian Pentecostalism
}

Jörg Haustein*

History of Religions and Mission Studies, Faculty of Theology, University of Heidelberg;

Kisselgasse 1, 69117 Heidelberg, Germany

joerg.haustein@wts.uni-heidelberg.de

The article revisits the issue of historiography in Pentecostal studies, seeking to connect this debate to recent theories of history coming from post-colonial and post-structuralist thought. The argument is that the historian of Pentecostalism should seek more than to reconstruct past events, but to offer a historical analysis of Pentecostal historiography. By drawing on four related theoretical insights into history and applying them to a concrete example from Ethiopian Pentecostalism, the article aims to contribute to the epistemological reflection of Pentecostal historiography.

Keywords: Ethiopia, History, Historiography

Historical studies have been an important and even initial factor in the wider academic debate about Pentecostalism. The central issues surrounding histories of Pentecostalism are well known: how to determine the movement's origin, how to navigate its historical plurality and fragmentation, how to

\footnotetext{
* I would like to thank the anonymous reviewers for their careful and insightful reading of this text, which helped to
} refine its argument. 
explain its rise, how to deal with the often poor quality of sources, how to interpret oral accounts, how to account for Pentecostal assertions of providential intervention - to name a few. It is the argument of this article, that the discussion and reflection of these issues may benefit from a look at the post-structuralist debate about historiography, because its emphasis on the analysis of historical narratives provides fresh insights into the epistemology of Pentecostal memory.

Over the years, the importance of narratives to Pentecostal history has occasionally been recognized. Already in 1986 Grant Wacker published an essay exploring Pentecostal views of history. ${ }^{1}$ Parsing the controversies about American Pentecostal history and contrasting them with the first accounts and their providential assertions, Wacker asked whether the "Golden Oldies are Still Worth Playing.” He seemed to think they are, though not as historical documents, but as sources for understanding the theological ritualization of Pentecostal experience. Almost two decades later, Mel Robeck showed that this approach can be a critical tool against historical revisionism, when he studied the ritualization of the initial evidence doctrine. ${ }^{2}$ Another helpful contribution to the discussion of historiography was August Cerillo's typology of historical approaches to Pentecostal origin. ${ }^{3}$ Studying not only theological, but also historical and anthropological accounts of Pentecostal beginnings, Cerillo differentiated four types of historical approaches: Providential, Historical Roots, Multicultural, and Functional. Drawing out the strength and weaknesses of each approach, Cerillo concluded that all four approaches taken together "promise a way toward a more comprehensive and historically satisfying synthesis of the story of the emergence of the American Pentecostal religious tradition.”4 However, this harmonious conclusion is a bit dissatisfying, since it levels the strong differences between the four historiographical types, which could instead be a point of departure for historiographical analyses.

1 Grant Wacker, “Are the Golden Oldies Still Worth Playing? Reflections on History Writing Among Early Pentecostals,” Pneuma 8, no. 2 (1986): 81-100.

2 Cecil M. Jr Robeck, “An Emerging Magisterium? The Case of the Assemblies of God,” Pneuma 25, no. 2 (2003): 164-215.

3 Augustus Cerillo Jr., “Interpretative Approaches to the History of American Pentecostal Origins,” Pneuma 19 (1997): 29-52.

4 Ibid., 52. 
There have been other contributions to the debate about Pentecostal historiography, for example William Kay's defense of providential narratives, ${ }^{5}$ Everett Wilson's critique of historical essentialism, ${ }^{6}$ or Dale Irvin's argument for a more fragmented sense of origin. ${ }^{7}$ However, Wacker and Cerillo are especially important for the argument of this article, since both emphasize the importance of narratives to understanding history. Both make clear that it is not simply the task of the historian to dig through the stories offered in order to get to the bottom of what actually happened. Instead, stories are an important historical research target themselves, since they are not just more or less appropriate linguistic containers for factual events, but interpretations rooted in certain points in time. In other words, historians should not try to look through the narratives offered, but at them.

This converges with a number of recent philosophies of history, because the linguistic and cultural turns have challenged the realism of the historiographical operation in two fundamental ways. ${ }^{8}$ First, the notion of facts outside of their linguistic representation has forcefully been called into question from a number of vantage points, ranging from feminist theory to post-colonial studies and post-structuralist philosophy. Secondly, historians themselves have begun to place historical writings within the realm of literary prose and subjected them to literary analysis, perhaps most famously in Hayden White's Metahistory from 1973. ${ }^{9}$ Both critiques emphasize the importance of language for the task of the historian. So on the one hand, historical events do not exist outside of linguistic signification. No doubt, humans live in time and "things happen”, but in order for lived experience to become an "event," and a "historical” one at that, a number of concepts are needed

5 William Kay, “Three Generations On. The Methodology of Pentecostal History,” EPTA Bulletin 11, no. 1+2 (1992): 58-70; William Kay, “Karl Popper and Pentecostal Historiography,” Pneuma 32, no. 1 (2010): 5-15.

6 Everett A. Wilson, “They Crossed the Red Sea, Didn’t They? Critical History and Pentecostal Beginnings,” in The Globalization of Pentecostalism. A Religion Made to Travel, ed. Marray W. Dempster, Byron D. Klaus, and Douglas Petersen (Oxford: Regnum Books International, 1999), 85-115.

7 Dale T. Irvin, “Pentecostal Historiography and Global Christianity. Rethinking the Question of Origins,” Pneuma 27, no. 1 (2005): 35-50.

8 Philipp Sarasin, Geschichtswissenschaft Und Diskursanalyse, Suhrkamp-Taschenbuch Wissenschaft; 1639 (Frankfurt am Main: Suhrkamp, 2003), 23-25.

9 Hayden White, Metahistory. The Historical Imagination in Nineteenth-Century Europe (Baltimore, Maryland: John Hopkins University Press, 1973). 
that are only available in the interpretive confines of language. On the other hand, historical descriptions, being part of linguistic signification, adhere to certain literary conventions, as do the stories of the historian's informants.

Historians thus have been reassigned their place within the political, cultural, and linguistic representations of the world which some had believed possible to transcend. Hayden White later put the philosophical implications of this in the following words:

[...] it was possible to believe that whereas writers of fiction invented everything in their narratives - characters, events, plots, motifs, themes, atmosphere, and so on - historians invented nothing but certain rhetorical flourishes or poetic effects to the end of engaging their readers' attention and sustaining their interest in the true story they had to tell. Recent theories of discourse, however, dissolve the distinction between realistic and fictional discourses based on the presumption of an ontological difference between their respective referents, real and imaginary, in favor of stressing their common aspect as semiological apparatuses that produce meanings by the systematic substitution of signifieds (conceptual contents) for the extradiscursive entities that serve as their referents. In these semiological theories of discourse, narrative is revealed to be a particularly effective system of discursive meaning production by which individuals can be taught to live a distinctively "imaginary relation to their real conditions of existence," that is to say, an unreal, but meaningful relation to the social formations in which they are indentured to live out their lives and realize their destinies as social subjects. ${ }^{10}$

In other words: the routinely distinguished fictional and realistic representations of the past are actually identical operations at a semiological level: in both cases a linguistic signification serves as placeholder for something outside of language. Fictional accounts stand in for fiction and realistic accounts for reality, and the linguistically demarcated difference between them leads to the possibility of distinguishing between the real and the imaginary. Once this foundational distinction is revealed to be part of human discourse rather than extra-discursive, it becomes understandable why narratives continue to be an important form of historiographical representation. There simply is no quality of lived experience which would dictate whether to represent something in literary or factual manner. All experiences lend themselves to factual and to narrative representation, and which of the two is more acceptable and how they can be told apart, is negotiated within a given discourse. Moreover, narrative forms lend themselves to more coherence and meaning-making in

10 Hayden White, ed., The Content of the Form. Narrative Discourse and Historical Representation (Baltimore, Maryland: Johns Hopkins University Press, 1987), x. 
comparison to factual accounts, such as linear chronologies.

So if fictional and factual significations are part of the same semiological apparatus of history, historians need to consider both: material evidence presented as a realistic signification of an event, and the more or less fictional forms of building a story around the same. This does not entail an “ahistorical stance” of "postmodernism” as is sometimes wrongfully alleged. ${ }^{11}$ Quite conversely, an extensive analysis of fictional representation depends on meticulous historical research, since the historian will always attempt to throw the full complexity of the historical entanglement at the narratives produced about the same, in order to read and interpret them as what they are: meaningful stories about the past.

The following remarks aim to sketch out such a historiographical approach which closely intertwines the analysis of narrative and realistic forms of representation, of stories and material evidence, and thereby connects the task of telling history to the task of critically reviewing historical knowledge. The aim is to show that by giving central room to the analysis of historical narratives, histories of Pentecostalism can better incorporate the plurality of the movement as well as its providential outlook, and yet stay true to the rigor of historical methodology.

\section{Background: Ethiopian Pentecostalism and the Chacha}

In order to bear out the theoretical reflections in detail, they will be applied to a specific example from Ethiopian Pentecostal history, which in turn necessitates a brief introduction to Ethiopian Pentecostalism. ${ }^{12}$ Ethiopia is a remarkable case, because there has been a noticeable shift of religious affiliation in this traditionally Orthodox and Muslim country. Over the past 25 years the share of Protestants has risen from little over 5 percent to almost 20 percent. ${ }^{13}$ This increase largely

11 See Robert M. Menzies, “Jumping Off the Postmodern Bandwagon,” Pneuma 16 (1994): 116.

12 These remarks will present a cumulative and largely uncritical account of Ethiopian Pentecostal history in order to provide some context. For a thorough (and necessary) deconstruction of this history and further references, see Jörg Haustein, Writing Religious History. The Historiography of Ethiopian Pentecostalism, Studien Zur Außereuropäischen Christentumsgeschichte (Asien, Afrika, Lateinamerika) 17 (Wiesbaden: Harrassowitz, 2011).

13 This is according to the Ethiopian census data. For a more detailed discussion of these figures and their implication, cf. Jörg Haustein and Terje Østebø, "EPRDF’s Revolutionary Democracy and Religious Plurality. Islam and Christianity in post-Derg Ethiopia,” Journal of Eastern African Studies 5, no. 4 (2011): 755-772. 
came at the expense of the Orthodox Church, whereas the overall proportions of Christians and Muslims have remained about constant. The rise of Protestantism is partially due to growing Pentecostal churches, but the lion share of Protestants still remains with mainline denominations. However, all Protestant churches have in recent years accommodated Pentecostal beliefs and practices, so that their services and theologies have become almost indistinguishable.

Pentecostalism is a fairly late arrival in Ethiopia, beginning with Finnish and Swedish Pentecostal mission initiatives in the 1950s. The Finnish couple Anna-Liisa and Sanfrid Mattson arrived in Ethiopia in 1951 and set up an umbrella organization for otherwise independent Finnish missionaries. In 1956 a female missionary belonging to this organization opened a work center in the Addis Ababa Merkato area and began spiritual meetings there, which allowed her to connect with some Ethiopian students. The most important mission initiative among the Swedish Pentecostals was the Swedish Philadelphia Church Mission, which set up a work center and a congregation in the southern town of Awasa in 1960. The relevance of the Swedish mission in Awasa for the early Pentecostal mainly lies in annual summer Bible schools the mission conducted. These revival meetings lasted several weeks and were attended mostly by students in their summer break from all over the country.

An indigenous Pentecostal movement gained momentum toward the middle of the 1960s, with a number of mostly young Ethiopians claiming the baptism of the Holy Spirit. Some of these youths attended the Finnish or Swedish missions, but quite a few congregated in mission-independent prayer groups, where they had come in contact with Pentecostal teachings through friends from the missions and literature. A number of these initiatives converged in Addis Ababa and founded the Full Gospel Believers’ Church in 1967. Only a few months after its foundation, the Full Gospel Church applied for registration as a religious association, which was a bold attempt reflecting the modernizing impulses of the Pentecostal youths. At that time Ethiopia was still governed by the old alliance between Emperor and the Ethiopian Orthodox Church and tenuous provisions for religious 
freedom had only been introduced very recently, mostly in order to accommodate foreign missions. Accordingly, the registration request failed, which also entailed the closure of the church's meeting places.

The Full Gospel Church at first complied with this ruling and relied on smaller meetings mostly in private homes. During this time, the Ethiopian Pentecostal movement encountered its first doctrinal division when one of its evangelists teamed up with Oneness Pentecostal missionaries and subsequently founded the Apostolic Church of Ethiopia. From the end of 1971 onward, the political pressure on Pentecostals again increased, culminating in the arrest of approximately 250 worshipers on Sunday, the $27^{\text {th }}$ of August 1972. The legal and political aftermath of this incident did not turn out in favor of the Pentecostals, even though they had managed to bring their case to the attention of the international press (there was even an article in the international edition of Newsweek ${ }^{14}$ ) and had found some Lutheran supporters, who sparked an investigation by the World Council of Churches.

In 1974 a popular revolution erupted in Ethiopia, which led to the overthrow of the emperor. Pentecostals at first were hopeful that now they would be able to attain religious liberty. The Full Gospel Church resumed public meetings in the summer of 1974 and immediately set up a new national structure. The renewed leadership power also entailed the second doctrinal division when the issue of Christian Deliverance erupted within the church. By 1976 the Ethiopian revolution had given way to a socialist military dictatorship, which forcibly aligned the Orthodox Church and the Muslim community, and soon began to crack down on other religious groups. Full Gospel congregations were shut down all over the country, leaders were put in prison for years without a trial, and a number of them suffered torture. The Pentecostal missions also began to turn over their work to Ethiopians between 1975 and 1978, and soon these new churches were closed and dispossessed as well. Only a small contingent of Swedish missionaries remained in the country, concentrating mostly on development work. Mainline Protestant churches were targeted during this

14 “Persecuting the Sects,” Newsweek. International Edition (January 15, 1973): 32. 
time as well, and much of Protestant Christianity, including almost all of the Pentecostals, remained underground throughout the time of the socialist regime.

After the regime had been brought to an end by a coalition of guerrilla liberation movements in 1991, the new government allowed Pentecostal churches and missions to resume public meetings and returned much of their dispossessed estate. All churches reported significant gains when they reopened, and continued to grow at an astonishing rate, often in competition with one another. Charismatic groups had emerged in the mainline churches to some degree before, but it was during this time of religious freedom that Charismatics became a vocal and visible majority in Ethiopian Protestantism.

As a result there now is a fragmented landscape of churches, smaller ministries, and evangelists, which need to be studied when investigating Ethiopian Pentecostal history. In such a plural setting there are of course many claims to stake in telling history, and the stories about the beginnings of Ethiopian Pentecostalism are accordingly diverse. In addition, not all of the first Pentecostals ended up in the Full Gospel Believers' Church, but joined mainline Protestant denominations or became independent ministers. Moreover, due to the past political suppression, there is hardly any archival material and almost no previous studies. Most of the written publications, reports and historical commemorations date to the past two decades, when a sizable pool of narratives has been produced, which often contest one another or clearly converge with the interests of a certain denomination or individual.

The main challenge to writing history in such a setting of course lies in the manifest politics of historiography. How can a historian resist getting pulled into the fray? And how can one avoid to boil down the narrative abundance of this source archive to a skeleton of facts, in which many parts still need to be filled in with best guesses? Moreover, how can the interests and the political thrust of informants become part of a historical analysis which goes beyond merely reproducing the plurality of encountered assertions? It is these kinds of practical or methodological questions which 
the following theoretical deliberations ultimately address.

The specific example to be used below relates to the debate of Ethiopian Pentecostal origins. Many histories give a central role to a certain evangelist from Kenya by the name of Chacha Omahe. Chacha visited Ethiopia only briefly on three occasions in 1963, 1964 and 1966. He mostly ministered at the Swedish Philadelphia Church Mission in Awasa, and in 1963 and 1964 he also visited Addis Ababa, though the Finnish Mission there only allowed him to speak once. His first visit in 1963 is linked by many sources to an initial outpouring of the Holy Spirit, thus attributing Chacha with a central role in Ethiopian Pentecostalism. We will see how certain discourses overlap in the person of Chacha Omahe, and how newer theories provide helpful insights for a historical analysis of this entanglement.

\section{Narrativity: An African Sparks the Fire}

In his Metahistory from 1973 Hayden White set out with the dictum that "there can be no 'proper history' which is not at the same time a 'philosophy of history'."15 White famously subjected 19th century historians (and philosophers) to a literary analysis, distinguishing three types of historical explanation, each with four possible modes. ${ }^{16}$ The first way of historical explanation is "by emplotment,” for which White proposed the four literary plots of Romance, Tragedy, Comedy, or Satire. The second level is explanation by argument, "seeking to explicate 'the point of it all'," by way of a Formist, Organicist, Mechanistic, or Contextualist approach. Finally, histories must seek some sort of ideological implication for the present, for which White suggested the possible world views of Anarchy, Conservatism, Radicalism, and Liberalism. Based on this structure, he asserted that any historian has to develop an explanatory strategy of selecting and combining the different modes of emplotment, argument, and ideological implication, in a "poetic act which precedes the formal analysis of the field" and in which "the historian both creates his object of analysis and

15 White, Metahistory. The Historical Imagination in Nineteenth-Century Europe, xi. 16 Cf. Ibid., 7-31. 
predetermines the conceptual strategies he will use to explain it.”17

White's clearly structuralist scheme of explaining 19th century historians may not be directly applicable to the study of Pentecostal history, but his mode of analysis - to study historical sources as literary works by querying their plots, arguments and ideological implications - is useful for mapping out the literary features encountered in the sources.

Let us look at our example. One of the most important narrative plots that is usually connected with the figure of Chacha was already established by the first written history of Ethiopian Pentecostalism, the unpublished "Documentary Report” by the Norwegian Lutheran missionary Tormod Engelsviken. In the preface to his manuscript Engelsviken defines his aim as follows:

This book is also a report on mission. The main characters are, however, not missionaries from the West, but Ethiopian students and other ordinary people [...] It is therefore also a report on how the Gospel can spread without foreign personnel, foreign money, big institutions, ambitious development programs and advanced theological education. ${ }^{18}$

With these words, Engelsviken introduces the central theme of his narrative: mission independence. His account of the Finnish and Swedish Pentecostal mission endeavors corresponds to this central interest. The missionaries’ arrival is sketched in brief without much detail regarding their different projects and initiatives. The converts of the mission are characterized as "completely ripe for harvest," ${ }^{19}$ but there are no reports of Spirit baptism. Furthermore, the missionary endeavor is complemented by other outside influences such as American Pentecostal literature, Bible study and prayer. Engelsviken concludes:

The ground was prepared by the ministry of the missionaries, the reading of evangelical literature and by personal preparation in Bible study and prayer. As expectations increased, only a spark was needed to set the young people aflame for Christ. This spark was not a missionary or guest speaker from the West, but an African evangelist from neighbouring Kenya. ${ }^{20}$

This summary lends itself to a number of observations: first, there seems to be an actual story of

17 Ibid., 31.

18 Tormod Engelsviken, Molo Wongel. A Documentary Report on the Life and History of the Independent Pentecostal Movement in Ethiopia 1960-1975 (Oslo: Unpublished Manuscript, The Free Faculty of Theology, 1975), 7.

19 Ibid., 21.

20 Ibid., 25. 
revival to tell, with its own build-up (“the ground was prepared”) and climax (“spark”). Secondly, an identifiable historic event is assumed to have initiated the revival. Third, since the missionaries had no direct involvement in this initial event, their ministry was merely part of preparatory groundwork, next to "evangelical literature” and personal "Bible study and prayer.” Finally, there is an implicit statement of missionary ineffectiveness, based on assumptions of African authenticity, because the key event is explicitly stated to have been linked to an "African” minister from “neighbouring” Kenya, and not to a "missionary or guest speaker from the West.”

Engelsviken now turns to Chacha’s ministry, through which the "gifts of the Spirit [...] became an experienced reality for the nucleus of those who were destined to become the human instruments for the revival God was going to send.”"1 The main point of this story is forcefully presented here:

It was not the white missionaries who had conveyed this experience, but one of Africa's own black sons. ${ }^{22}$

Following Chacha's ministry, Engelsviken immediately narrates the break with the missionaries at the Finnish Mission, which is presented in part as a consequence of Chacha's ministry, though it occurred over three years later. Here the story about the beginnings of Ethiopian Pentecostalism has reached its goal. The missions had been one of many instruments to prepare revival, but in the end they were unable to convey the central Pentecostal experience to their Ethiopian followers. This was left to “one of Africa’s own black sons," who in turn helped to bring about the only conceivable consequence to this story: national emancipation.

Engelsviken thus provided a clear narrative plot of revival, all prior events are preparatory and build up the Ethiopian youths. The climax to the story of Ethiopian beginnings was in the Spirit falling under the ministry of Chacha Omahe, and everything unfolded from there. This plot was connected to his main argument for African independency: just as the spark lighting the revival fire eventually consumed all preparatory groundwork, the work of the "African evangelist” outshone missionary

21 Ibid., 28-29.

22 Ibid., 29. 
involvement and left a much deeper impact. The ideological implication is clear: (latest) from now on, “Africa’s own black sons” will spread the gospel without foreign assistance.

The main point in focusing on the emplotment, argument and ideological implications contained in Engelsviken's Chacha narrative is not to dispute Chacha's role or to reassess is “actual” influence. Much of the available source material already does this and provides other versions of how the revival "really” began, which stand in contrast to Engelsviken's narrative. Rather, as Hayden White has remarked in one of his later essays, the reality of events is not determined by their occurrence, but by the possibility of their inclusion in historical narratives:

[E]vents are real not because they occurred but because, first, they were remembered and, second, they are capable of finding a place in a chronologically ordered sequence. In order, however, for an account of them to be considered a historical account, it is not enough that they be recorded in the order of their original occurrence. It is the fact that they can be recorded otherwise, in an order of narrative, that makes them, at one and the same time, questionable as to their authenticity and susceptible to being considered as tokens of reality. In order to qualify as historical, an event must be susceptible to at least two narrations of its occurrence. Unless at least two versions of the same set of events can be imagined, there is no reason for the historian to take upon himself the authority of giving the true account of what really happened. The authority of the historical narrative is the authority of reality itself; the historical account endows this reality with form and thereby makes it desirable by the imposition upon its processes of the formal coherency that only stories possess. ${ }^{23}$

Thus, instead of asking whether Engelsviken tells "real” history, a critical analysis of historiography seeks to explain how a given narrative creates the reality of history: how Chacha is established as a token for the historicity of Spirit outpouring in Ethiopia, how competing (missionary) accounts are implicitly contested, and how the formal coherency of the Chacha story is created in emplotment, argument and ideological implication, thereby endowing historical reality with form.

This "formal coherency" of historical narratives, according to White, is one "to which we ourselves aspire.” Histories deliver a temporary closure to our world, in which "reality wears the mask of a meaning, the completeness and fullness of which we can only imagine, never experience.” ${ }^{24}$ White

23 Hayden White, “The Value of Narrativity in the Representation of Reality," in The Content of the Form. Narrative Discourse and Historical Representation, ed. Hayden White (Baltimore, Maryland: John Hopkins University Press, 1987), 20.

24 Ibid., 21. 
sums up his point:

Insofar as historical stories can be completed, can be given narrative closure, can be shown to have had a plot all along, they give to reality the odor of the ideal. This is why the plot of a historical narrative is always an embarrassment and has to be presented as "found" in the events rather than put there by narrative techniques. ${ }^{25}$

\section{Discourse: The Empty Signifier of Spirit Outpouring}

This veiled desire for a meaningful and full coherence of history, is what turns history into an object of desire and thus constitutes the competitiveness of historical discourse. Critical history therefore must not only analyze the narrativity of a historical account but also its politics of articulation. This discursive entanglement of meaning and politics, semantics and hegemony has been convincingly explained by Ernesto Laclau's and Chantal Mouffe’s political theory of hegemony.

Laclau and Mouffe do not directly deliberate questions of historiography but of political theory, namely how political relations of power - hegemony and antagonism - can be conceptualized without the "illusion of immediacy," ${ }^{26}$ i.e. without the notion of objective social relations resulting in certain configurations of the political. Instead, the social is "conceived as a discursive space" 27 in which “contingent articulation” enounces a “central dimension of 'politics',"”28 or in other words: "the political [is conceived] not as a superstructure but as having the status of an ontology of the social. ${ }^{29}$

Laclau's and Mouffe's understanding of discourse begins with Ferdinand de Saussure's established semiotic insight that "language (and by extension, all signifying systems) is a system of differences, i.e. that linguistic identities — values — are purely relational.” ${ }^{30}$ However, if the meaning of signifiers does not rest in a direct correspondence with their (material) referents, but in their

25 Ibid.

26 Ernesto Laclau and Chantal Mouffe, Hegemony and Socialist Strategy. Towards a Radical Democratic Politics, 2nd ed. (London: Verso, 2001), xi.

27 Ibid., x (emphasis Laclau/Mouffe).

28 Ibid., xii.

29 Ibid., xiv.

30 See Ernesto Laclau, “Why Do Empty Signifiers Matter to Politics?,” in The Lesser Evil and The Greater Good. The Theory and Politics of Social Diversity, ed. Jeffrey Weeks (London: Rivers Oram Press, 1994), 168. See also Jacob Torfing, New Theories of Discourse. Laclau, Mouffe and Žižek (Oxford: Blackwell, 2005), 87. 
relationship to other signifiers, then "the totality of language is involved in each single act of signification.”31 This in turn presupposes some sort of temporary or fictitious closure to the system of signification in order to create meaning, because if "the meaning of a term was purely relational and determined only by its opposition to all the others," then "we are presented with the conditions of possibility of a closed system: only within it is it possible to fix in such a manner the meaning of every element."32

Closure therefore is impossible in a positive or ontological sense, but it is also necessary, because without a "fictitious fixing of meaning there would be no meaning at all."33 However, this temporary closure cannot be represented directly, for example in a relation of opposition or contradiction marking the inside and outside of a signifying system or discourse. This is because opposition and contradiction are differential relations in themselves, and thus such a signification of discursive closure would only be absorbed into an extended flow of differences. ${ }^{34}$ Laclau therefore suggests that the constitutive outside of a discourse's limit can only be conceptualized as "pure negativity,” signified not in terms of relation but as the subversion of the process of signification itself. ${ }^{35}$ Therefore this pure negativity, this antagonistic outside of a system, is signified within the discourse by subverting differential relations: they are collapsed into a chain of equivalences. In other words: all differences between signifiers in a given discourse pale in comparison to the antagonistic outside. In Laclau's words: "It is only by privileging the dimension of equivalence to the point that its differential nature is almost entirely obliterated—-that is, emptying it of its differential nature- -that the system can signify itself as a totality.”36

This chain of equivalences cannot be represented with an overarching signifier of its own, but "it

31 Laclau, “Why Do Empty Signifiers Matter to Politics?,” 168.

32 Laclau and Mouffe, Hegemony and Socialist Strategy. Towards a Radical Democratic Politics, 113.

33 Ernesto Laclau, “The Death and Resurrection of the Theory of Ideology,” Journal of Political Ideologies 1, no. 3 (1996): 205.

34 Cf. Laclau, "Why Do Empty Signifiers Matter to Politics?,” $168 f$.

35 Ibid., 170.

36 Ibid., 171. 
has to borrow the latter from some entity constituted within the equivalential space.” ${ }^{37}$ The borrowed signifier looses all of its particularities when it stands for the equivalential chain as a whole. This is the empty signifier: a signifier representing the common identity while remaining indeterminate since it stands for the collapse of all differences within a given discourse. ${ }^{38}$ Which signifier from the equivalential chain takes on this role is not determined per se, but the result of a “particular conjuncture” producing relations of power: “This relation by which a particular content becomes the signifier of the absent cotmmunitarian fullness is exactly what we call a hegemonic relationship." ${ }^{39}$ Even more so: naming the empty signifier is not "a conceptual operation of finding an abstract common feature” but "a performative operation constituting the chain as such.”40

How does this political theory relate to Pentecostal historiography? Laclau and Mouffe show how historical (and any other) meaning-making is necessarily connected to political relations of hegemony. The infinite differential chain of historical signifiers (terms, names, stories, interpretations, etc.) has to be delimited in order to make meaning possible, and this delimitation is represented within the Pentecostal historical discourse by privileging a certain event, name, story, or term and emptying it of its particularities, so that it may stand for a chain of equivalent events, stories, names, or terms.

The Chacha story has assumed the role of "empty signifier” for the historical discourse about the origins of Ethiopian Pentecostalism. As such it must be emptied of historical particularities in order to stand for a whole chain of equivalent stories about “initial outpouring” events in Ethiopia. Accordingly, most stories about the Kenyan evangelist are extremely condensed and streamlined to fit the narrative form of “initial Spirit outpouring.” They leave out all historical background

37 Ibid., 174. If the equivalential chain could have a signifier of it own (i.e. one which is not borrowed from the equivalential chain), this would result in representation of the "subversion of signification" as yet another relation of difference, and the system closure would collapse.

38 In a later publication, Laclau gives the examples of “order”, “justice”, “equality”, or "freedom” for this, and continues: It would be a waste of time trying to give a positive definition of 'order' or 'justice' - that is, to ascribe to them a conceptual content, however minimal it might be. The semantic role of these terms is not to express any positive content but, as we have seen, to function as the names of a fullness which is constitutively absent." See Ernesto Laclau, On Populist Reason (London: Verso, 2005), 96.

39 Laclau, "Why Do Empty Signifiers Matter to Politics?,” 175.

40 Laclau, On Populist Reason, 97. 
information about Chacha, even though he was a well-established evangelist and church leader, first in the (American) Elim Missionary Assemblies in Kenya and later in his own church. ${ }^{41}$ He was affiliated with Joseph Mattsson-Boze, who also initiated Chacha's invitation to Ethiopia. So he was not an unknown or marginal figure, rather, he was quite well established in East African Pentecostalism. Yet, Ethiopian informants are not familiar with Chacha’s educational background, his denominational affiliation, his role in Kenya, nor the origins of his contact with Ethiopia. Even the fact that Chacha visited Ethiopia three times is often ignored; instead his three visits are collapsed into one which clearly marks the initial outpouring event - occasionally with references to Acts 2. Moreover, Chacha assumes this role wherever he goes, whether he preaches with missionary consent in Awasa or teaches at the Finnish mission in Addis Ababa with controversies following. In the words of an informant: "he just released the Holy Spirit." 42

It is clear from the discussion of Laclau and Mouffe that this establishment of an empty signifier equating a range of historical events is also a political claim, a hegemonic operation, which of course has not gone unchallenged. Especially missionaries have laid claim to the same equivalential chain of “initial outpouring” by privileging other stories as empty signifier and de-emphasizing Chacha's role. The Swedish missionary Karl Ramstrand, for example, who invited Chacha to the initial visit in 1963, downplayed the Kenyan’s role in his 1986 memoirs. Ramstrand introduced Chacha as someone who "is not a great teacher but he can set people lose," 43 thus articulating the need for proper oversight. More importantly, the 1963 conference was not the first outpouring of the Holy Spirit in Ramstrand's memoirs. Instead, he narrated a different event which occurred one year earlier and revolved around his young daughter Kristina speaking in tongues at a prayer meeting. ${ }^{44}$ His wife, in her 2002 memoirs, called this earlier event a "spiritual breakthrough" and asserted that "suddenly the Holy Spirit fell over all, like we read how it happened on the first Pentecost day in

41 For historical details about Chacha, see Haustein, Writing Religious History. The Historiography of Ethiopian Pentecostalism, 70-73.

42 Oral interview, Addis Ababa, April 1, 2004.

43 Karl Ramstrand, Det Heliga Äventyret (The Holy Adventure) (Stockholm: Den Kristna Bokringen, 1986$), 133$. 44 Ibid., 125. 
Jerusalem at the time of the first Christians." 45 A similar case can be made about the Finnish Mission, whose involvement in Ethiopia has most extensively been laid out in an unpublished paper from $2001 .{ }^{46}$ The paper does not mention Chacha at all, but claims that the first Spirit baptism in Ethiopia occurred at a Finnish mission Bible Study in $1962 .{ }^{47}$ Both of these competing stories provide very little historical information. Just like the Chacha narratives they are stripped of historical particularities in order to stand for the larger event of the Spirit's outpouring in Ethiopia as the references to Acts 2 make clear.

All of these narratives certainly pertain to past occurrences. Yet this is not the full point of their inclusion in histories of Ethiopian Pentecostalism. Instead, they are part of a historical discourse, claims to an empty signifier, which in turn establishes the historical identity and meaning of Ethiopian Pentecostalism. The hegemonic politics of articulation therefore are not an accidental or undesirable byproduct of history but an essential and unavoidable feature of meaning making. Historians of Pentecostalism need to analyze such politics and furthermore detect the empty signifier(s) by which the Pentecostal community upholds and competitively defines its history.

\section{Genealogy:The Emergence of Chacha}

Such discursive formations of course are not static and have a history in themselves that needs to be subjected to historical analysis. This is an established point in historical research: Historians explore the genesis of present historical knowledge by following chains of references and searching for veiled or forgotten material. If successful, they arrive at a plethora of sources and interpretations. However, as Michel de Certeau has pointed out, the practice of writing history then inverts the direction of historical inquiry: the past, which was the vanishing point during research, now becomes the point of origin, whereas the present, from where the researcher departed, becomes the

45 Ruth Ramstrand, Guds Lilla Piga Far Dit Pepparn Växer (God’s Little Maid Goes Where the Pepper Grows) (Huskvarna, 2002), 187.

46 Kyösti Roininen, “A Condensed History of the Finnish Mission in Ethiopia”, 2001.

47 Ibid., 5. 
goal of the resulting text. ${ }^{48}$ According to de Certeau, historical text therefore is a mirror writing obfuscating the direction of historical research, which, by contrast, originated in the present and spoke its findings into the past.

Against such arbitrary origins and the implicit finality of historical writings, Michel Foucault has heralded the genealogy as an " 'effective' history”, which "opposes itself to the search for 'origins'” and rejects "the meta-historical deployment of ideal significations and indefinite teleologies."49 Using Nietzsche's Genealogy of Morality as a point of departure, Foucault sought to "dispel the chimeras of origin"50 by two related but entirely different concepts, Herkunft and Entstehung, descent and emergence. Herkunft or descent means to

[...] to maintain passing events in their proper dispersion; it is to identify the accidents, the minute deviations - or conversely, the complete reversals - the errors, the false appraisals, and the faulty calculations that gave birth to those things that continue to exist and have value for us. ${ }^{51}$

Entstehung or emergence, on the other hand, should not be viewed as "the final term of a historical development," but the genealogy must seek “to reestablish the various systems of subjection: not the anticipatory power of meaning, but the hazardous play of dominations."52 Thus, descent recovers disparity instead of the singularity of origin, and emergence disperses the notion of finality by historicising developments in the struggle of concrete forces. So instead of traveling forward through time to trace what emerged out of supposed origins, historical research and writing are archaeological operations, departing from the present, rediscovering fragmented layers and exposing the contingency of history and historical knowledge.

In applying Foucault's genealogy to the story of Chacha Omahe, two aims must therefore be pursued. One is to depart from the present configuration and to recover the multiple

48 See Michel de Certeau, The Writing of History (New York: Columbia University Press, 1988), 86-99.

49 Michel Foucault, "Nietzsche, Genealogy, History," in Language, Counter-Memory, Practice, ed. Donald F Bouchard (Ithaca, New York: Cornell University Press, 1977), 140.

50 Ibid., 143.

51 Ibid., 152.

52 Ibid., 148. 
contemporaneous interpretations of his ministry. The second aim is to point out how this multiplicity of interpretations was condensed to the current dominant forms of historical knowledge about this man.

When excavating contemporaneous accounts about Chacha there is a clear plurality of stories. None of the events mentioned above already had their historical function as the beginning of the Ethiopian revival. Chacha’ ministry was characterized as powerful in a Swedish magazine report, but he did not have a definitive initial role. ${ }^{53}$ Instead the article narrated a little story of initial dissent, which is forgotten by almost all later histories: a number of Ethiopians did not believe Chacha and initially left the meeting. The Swedish magazine also contained a report about the earlier Spirit outpouring at the Swedish mission, but contrary to the Ramstrands' later accounts, there is no mention of tongues and the headline simply reads "Ethiopia - a ripe harvest field." ${ }^{4}$ On the Finnish side, neither Chacha nor the earlier Spirit baptism are mentioned by missionary letters. Instead, their aim seems to have been a rapid end-time salvation of the lost rather than a Pentecostal outpouring, since they believed that the Lord's return was imminent. Therefore, what later became key events for the "initial outpouring” of the Holy Spirit in no way were clearly established or defined as such at the time of their occurrence.

In exploring how Chacha became such a central and disputed figure in historical writings, it is necessary to return to the Norwegian missionary Tormod Engelsviken and his documentary report of 1975. Engelsviken’s sources almost exclusively came from the Full Gospel Believers’ Church, which was very wary of missionary influence, especially since some of its founders had a background in the missions. For this group, Chacha was the ideal founding father: an evangelist of non-Western origins rooted in world-wide Pentecostalism, but without a lasting presence in Ethiopia. It is no surprise then, that one of the co-founders, who later distanced himself from the

53 Harald Johansson, “Pingsteld Över Etiopien (Pentecost Fire Over Ethiopia),” Evangelii Härold, no. 48 (1963): 4. 54 Karl Ramstrand, “ETIOPIEN - Ett Mognande Skördefält (Ethiopia - a Ripe Harvest Field),” Evangelii Härold 45 (1962): 6-7. 
Full Gospel Believers' Church and expressed regret about the split from the Finnish Mission, also diminished Chacha's role in an interview and attributed to him nothing but a "fourth grade education." 55

Engelsviken's narrative of mission independence further amplified Chacha's role, but the lasting influence of his “Documentary Report” is due to other historical circumstances. Engelsviken wrote at the time of the Ethiopian revolution, which quickly turned against Pentecostals. His manuscript therefore remained the only extensive history of Ethiopian Pentecostalism for over a decade, and while it was never published, it was widely circulated and could be found in the relevant seminaries. From there the story proliferated into bachelor theses and other publications. It was also Engelsviken, who first reversed Chacha Omahe’s name to Omahe Chacha, which is what he is erroneously called in most publications now.

\section{Context: An Indefinitely Postponed Conclusion}

The mode of historiography proposed thus far consisted of three primary interests: to explore the creation of the reality of history in a literary analysis of narratives, to outline the politics of Pentecostal discourse by identifying empty signifiers, and to recover the disparity of origins and the contingency of historical knowledge in an archeological excavation of the source archive. As was argued by Hayden White, historiography is not a necessary by-product of writing about the past, but the place where our lived experience is turned into historical reality. The selection of events reported, the narrative structure adopted, the arguments implied or made explicit - they all give a certain "closure” to the past, and they make possible the articulation of history as well as of historical meaning. The discourse theory of Laclau and Mouffe showed that such closures are structurally necessary but historically contingent, and therefore they are subject to political dynamics, as different groups, sources, and authors privilege a certain event as “empty signifier” for what constitutes their discourse. For the historian, such debates are an important field of study, and

55 Oral interview, Addis Ababa, March 30, 2005. 
Foucault's concept of genealogy can provide a sense of direction in how to navigate this field:

historical writings should seek to restore the multifarious complexity of the past interpretations, and delineate how some of them attained a certain hegemony in the historical archive.

However, what is the epistemological status of a history based on the analysis of historiography? Is it a meta-history, a secondary treatment of historic representation that has itself been liberated from the burden of telling history? Or to the contrary, is it a part of that which it seeks to describe, subject to the same dynamics of narrativity, discursive hegemony, and historical contingency?

There is much that speaks for the latter conclusion, because the analysis proposed above is closely entangled with the discourse it describes. Just like other histories it hopes to alter the historical debate by critiquing the literary features of a story or exposing its political context. More importantly though, the analysis depended on its sources perhaps to a larger degree than classical historiography, for the primary content of the analysis is determined by what is strongly debated in the publications, manuscripts and interviews. The stories contained therein form the essential material to analyze, and the terms discussed are nothing but citations.

For this reason Jacques Derrida cautioned against a discourse analysis that seeks to assume an exterior position, a supra-historical view of history. In "Structure, Sign, and Play in the Discourse of the Human Sciences" he contended that all "destructive discourses [. . . ] are trapped in a sort of circle:”

This circle is unique. It describes the form of the relationship between the history of metaphysics and the destruction of the history of metaphysics. There is no sense in doing without the concepts of metaphysics in order to attack metaphysics. We have no language — no syntax and no lexicon - which is alien to this history; we cannot utter a single destructive proposition which has not already slipped into the form, the logic, and the implicit postulations of precisely what it seeks to contest. ${ }^{56}$

In other words: the critical analysis of Pentecostal historiography will easily be subject of the same dynamics it seeks to explain. The analysis of the plots, arguments and ideological implications of

56 Jacques Derrida, “Structure, Sign, and Play in the Discourse of the Human Sciences,” in Writing and Difference, ed. Jacques Derrida (London: Routledge, 1978), 280. 
Engelsviken's narrative quietly introduced a plot about authorial intent, made an argument about the ideological context of all sources, and led to the ideological implication that there can be no such thing as “objective” history. The deconstruction of the empty signifier "Initial Outpouring” was made possible by the introduction of the empty signifier "discourse". The chimera of origin may have been dispelled by the disparity of contemporaneous sources, but the analysis gave a certain original quality to Engelsviken's report. And so on.

This referentiality of histories and their sources goes beyond semiotic and structural parallels. It is connected to the production of text itself, as Derrida has also shown. In "Signature Event Context" he argued that all writing supposes a dual absence: that of the addressee and that of the author, since writing must remain legible when the author or any potential addressee are absent. Therefore,

[t]o write is to produce a mark that will constitute a kind of machine that is in turn productive, that my future disappearance in principle will not prevent from functioning and from yielding, and yielding itself to, reading and rewriting. ${ }^{57}$

Two consequences follow: first, any writing, any sign must be iterable, capable to be copied, repeated and cited; and secondly by this iterability, as Derrida says, all signs "can break with every given context, and engender infinitely new contexts in an absolutely nonsaturable fashion." ${ }^{\text {„5 }}$ The point of this inherent link between repetition and alterity is that texts are not understood by reference to an ordinary context, but because they are a citation of another text, which in turn cites another one, and so on. Histories therefore are recognizable not because they are positively related to past physical events, but because they are citations of other accounts. As histories continuously cite previous texts and contexts, thereby breaking with them and engendering new ones, historical meaning is continuously deferred, altered, permuted and ultimately postponed. This is the dynamic of the différance as described by Derrida. ${ }^{59}$ Just as the incessant differing of signifiers defers signification, the telling of histories continuously transforms and thereby postpones historical 57 Jacques Derrida, “Signature Event Context,” in Margins of Philosophy, ed. Jacques Derrida (Chicago: University of Chicago Press, 1982), 316.

58 Ibid., 320.

59 Jacques Derrida, “Différance,” in Margins of Philosophy, ed. Jacques Derrida (Chicago: University of Chicago Press, 1982), esp. 7-12, 20. 
meaning. History as such is no more possible than the deferred presence of the sign: it is a project for the present and the future which will therefore not come to rest within a given community.

The need to talk about Chacha in a treatment of early Ethiopian Pentecostal history arose from the stories found in historical discourse and the role he plays therein. Each new articulation about the Kenyan evangelist has the potential of altering what can be said about him and his role in new narratives. Yet every time his story is recited, with critical intention or not, his importance to Ethiopian Pentecostal discourse is affirmed. Chacha has ceased to exist as a historical person - if ever he did in Ethiopian Pentecostal discourse - but he lives on as a literary figure of historical accounts that continues to enter new contexts, as this article itself demonstrates.

What then is the truth to Chacha's story, its "real meaning”? Is it in the events themselves, that he was there in 1963, spoke, shouted, and prayed in tongues? Is it in that many Ethiopians identified him as their Pentecostal teacher? Is it in that he became the ideal father figure for a church articulating its history as one of missionary independence? Is it in his potential to become a central actor in a Norwegian missionary's story about an indigenous church? Or is it in becoming a suitable example for these theoretical remarks? The figure of Chacha not only has many origins, it has many places, and for a historian avoiding the "chimera of origin” as well as radical constructivism, there is no answer to the question of meaning outside of a given context.

Thus, while such a critical historiography of Ethiopian Pentecostalism carefully studies material artifacts and narrative representations, it does not attempt to define the meaning of events nor purport to know the "real story". Instead it is a literary, political, and historical analysis of what has been said about the past, aimed at recovering the unsaid, the marginalized, even to hint at the impossibilities, the limits of the Pentecostal historical discourse. This enables historians to accommodate and to sustain the plurality of Pentecostal historical memories in their academic accounts, while providing an independent analysis and furthering the historical debate. 